\title{
The effect of water-level fluctuations on swamp forest colonization by seedlings of Tabebuia cassinoides DC. (Bignoniaceae)
}

\author{
Pablo José Francisco Pena Rodrigues*, Mariana de Andrade Iguatemy \\ Instituto de Pesquisas, Jardim Botânico do Rio de Janeiro, Rio de Janeiro, Brazil; *Corresponding Author: pablo@jbrj.gov.br
}

Received 14 September 2011; revised 14 October 2011; accepted 27 October 2011.

\begin{abstract}
Establishment of Tabebuia cassinoides seedlings is related to water-level fluctuations in southeastern Brazil swamp forests. Nine years of annual monitoring of $\mathbf{4 8}$ individuals established during a drought in November 1997, when the swamp was unflooded, suggested that their establishment depends on this unpredictable event. This conclusion is further sustained by the wide variability of the seedling cohort size structure, and the fascicular root conformation that holds the shoots erect.
\end{abstract}

Keywords: Tropical Rain Forest; Wetland; Seedling Establishment; Safe Site; Root Morphology

Germination and seedling establishment in wetlands are poorly understood [1], and in most cases involve adaptations to survive oxygen deprivation [2,3]. Therefore, flooding is the main cause of low frequency of germination [4]. Seed buoyancy and long-term dormancy are often listed as important traits that allow seeds to survive and/or reach safe sites $[5,6]$ that are crucial for their development.

Even understory forest plants can serve as safe sites. For instance, the Brazilian swamp forest tree Tabebuia cassinoides DC. (Bignoniaceae) germinates inside the tanks of the understory bromeliad Nidularium procerum Lindm [7]. However, not all swamps in southeastern Brazil have understory bromeliads, and young T. cassinoides seedlings are flood-intolerant. Therefore, although asexual reproduction has been reported as an important characteristic of this species [7], other seed-establishment strategies must operate, to account for the high abundance of this species in most Brazilian swamps [8], even if we consider that only a small fraction of the seeds produced will survive to maturity [9].

In November 1997, a severe drought occurred during the rainy season in a swamp forest of the Parque Estadual da Serra do Mar, Núcleo Picinguaba $\left(23^{\circ} 21^{\prime} \mathrm{S}, 44^{\circ} 51^{\prime} \mathrm{W}\right)$, São Paulo state, southeastern Brazil. This swamp did not have a dense bromeliad understory. Therefore, it provided a good location to test the hypothesis that in these types of swamp forest, seedling establishment of this species occurs in years when the water table recedes. On this occasion, 48 newly germinated seedlings of an unflooded cohort of $T$. cassinoides were chosen at random and tagged. At the unflooded site we also observed the establishment of many terrestrial herbs. From November 1997 to December 2006 the seedlings were monitored annually for mortality, and beginning in 2000 they were measured for height and basal diameter. From 1998 to 2006 the site was continuously flooded (ca. $40 \mathrm{~cm}$ depth). Between 1998 and 2002, mean annual mortality was only 6.06 percent $( \pm 1.59)$. Simultaneously, herb density declined drastically (pers. obs.). Finally, during 2002-2003, 28 percent of the cohort died and a total of 26 individuals remained alive (Table 1).

Although this deciduous tree flowered and set seeds every year (between August and November), no new seedlings became established at this site. This could be due to intolerance of the seeds or seedlings to permanent flooding, or to transport of seeds to other sites by water. Therefore, low water levels may favor species germination, as shown in Chinese wetlands [10].

Height and basal diameter of cohort members showed wide variation from November 2000 to December 2006 (Table 1), and diameter was always closely correlated to height $\left(r^{2}>0.89\right.$; Table 1). The cohort density stability indicated no density-dependent or size-dependent mortality patterns.

The fascicular root morphology of the saplings seems to hold the shoots erect, which might be important for fixation or for maintenance of a larger flood-free surface area of the shoots, as is important for internal aeration [11]. Therefore, the onset of root fixation in unflooded soil conditions, allowing substrate trapping, may be cru- 
Table 1. Summary of structural parameters of a Tabebuia cassinoides DC. (Bignoniaceae) cohort established in 1997 at Picinguaba, São Paulo, Brazil during a severe drought.

\begin{tabular}{|c|c|c|c|c|c|c|c|c|c|c|c|c|}
\hline yr/period & 1997 & 1999 & & 2000 & & 2001 & & 2002 & & 2003 & & 2006 \\
\hline Total N & 48 & 44 & & 40 & & 37 & & 35 & & 26 & & 22 \\
\hline Deaths (\%) & & 8.33 & 9.09 & & 7.5 & & 5.41 & & 25.7 & & 15.4 & \\
\hline Diameter $^{\mathrm{a}}\left(\mathrm{mm}^{2}\right)$ & & & & $19 \pm 7$ & & $19 \pm 8$ & & $21 \pm 8$ & & $22 \pm 6.7$ & & $25 \pm 7$ \\
\hline Height $^{\mathrm{a}}(\mathrm{cm})$ & & & & $137 \pm 60$ & & $141 \pm 64$ & & $141 \pm 68$ & & $165 \pm 66$ & & $188 \pm 73$ \\
\hline Diameter vs. Height ${ }^{c}$ & & & & 0.89 & & 0.88 & & 0.66 & & 0.85 & & 0.81 \\
\hline Skewness $^{\mathrm{d}}$ & & & & 0.54 & & 0.35 & & 0.39 & & 0.36 & & 0.27 \\
\hline
\end{tabular}

${ }^{\mathrm{a}}$ mean $\pm \mathrm{SD}$; ${ }^{\mathrm{b}}$ relative diameter growth rate $-\mathrm{cm} \cdot \mathrm{cm}^{-1} \cdot$ year $^{-1}[14] ;{ }^{\mathrm{c}} \mathrm{r}^{2}, \mathrm{p}<0.005$; ${ }^{\mathrm{d}}$ size structure based on basal girth.

cial to survival in the subsequent deep flooding, as suggested for Carapa guianensis Aubl. in Amazonian varzea forests [12]. In some restored wetlands, low water levels favored the establishment of $T$. cassinoides [13]. Other local swamp tree species, such as the Clusiaceae Symphonia globulifera L.f. and Calophylum brasiliense Cambess., that also have seeds that float on the water, differently from $T$. cassinoides, germinate forming pivotal root structures that after fixation keep their shoots static and erect. These root patterns may restrict the ability of these species to colonize permanently and deeply flooded sites. Indeed, C. brasiliense occurs in Picinguaba wetlands, but mainly in shallow swamps (or periodically flooded sites). This pattern was previously observed at the National Reserve of Poço das Antas [7].

Our observations suggest that the seedling colonization pattern of Tabebuia cassinoides is dependent on synchronicity between annual seed production and an apparently stochastic water-level fluctuation. Thus, survival chances in the swamp may also be related to root morphological patterns and to success in reaching a safe site during a drought period.

\section{ACKNOWLEDGEMENTS}

We thank the Ecology Department of the Federal University of Rio de Janeiro for logistical support, and Fábio R. Scarano, Andrea Costa and Rodolfo C. Real de Abreu for suggestions, and Janet Reid by the linguistic advice.

\section{REFERENCES}

[1] Leck, M.A. (1989) Wetland seed banks. In: Leck, M.A., Parker, V.T. and Simpson R.L. Eds., Ecology of soil seed banks, Academic Press, London, 283-305.

[2] Crawford, R.M.M. (1989) Studies in plant survival. Blackwell Scientific Publications, Oxford, 296.

[3] Schupp, W.E. (1995) Seed-seedling conflicts, habitat choice, and patterns of plant recruitment. American Journal of Botany, 82, 399-409. doi:10.2307/2445586
[4] Borges, K.H., Viana, V.M. and Paulo, R.A. (2000) Produção de sementes e manejo da caixeta. Scientia Forestalis, 57, 111-122.

[5] Harper, J.L. Willians, J.T. and Sagar, G.R. (1965) The behaviour of seeds in the soil: The heterogeneity of soil surfaces and its role in determining the establishment of plants. Journal of Ecology, 53, 273-286. doi:10.2307/2257975

[6] Scarano, F.R. (1998) A comparison of dispersal, germination and establishment of woody plants subjected to distinct flooding regimes in Brazilian flood-prone forests and estuarine vegetation. In: Scarano, F.R., Franco, A.C. Eds., Ecophysiological Strategies of Xerophytic and Amphibious Plants in the Neotropics, Série Oecologia Brasiliensis, 4, 176-193.

[7] Scarano, F.R., Ribeiro, K.T., Moraes, L.F.D. and Lima, H.C. (1997) Plant establishment on flooded and unflooded patches of a freshwater swamp forest in southeastern Brazil. Journal of Tropical Ecology, 14, 793-803. doi:10.1017/S0266467400011007

[8] Gentry, A.H. (1992) Bignoniaceae. Part II (Tribe Tecomeae). Flora Neotropica Monograph, 25, 1-370.

[9] Petit, R.J. and Hampe, A. (2006) Some evolutionary consequences of being a tree. Annual Review of Ecology and Systematics, 37, 187-214.

[10] Liu, G., Zhou, J., Li, W. and Cheng, Y. (2005) The seed bank in a subtropical freshwater marsh: Implications for wetland restoration. Aquatic Botany, 81, 1-11. doi:10.1016/j.aquabot.2004.07.001

[11] De Simone, O., Müller, E., Junk, W.J. and Schmidt, W. (2002) Adaptations of central Amazon tree species to prolonged flooding: Root morphology and leaf longevity. Plant Biology, 4, 512-522. doi:10.1055/s-2002-34127

[12] Scarano, F.R., Pereira, T.S. and Rôças, G. (2003) Seed germination during floatation and seedling growth of $\mathrm{Ca}$ rapa guianensis, a tree from flood-prone forests of the Amazon. Plant Ecology, 168, 291-296. doi:.10.1023/A:1024486715690

[13] Zamith, L.R. and Scarano, F.R. (2010) Restoration of a coastal swamp forest in southeast Brazil. Wetlands Ecology and Management, 18, 435-448. doi:10.1007/s11273-010-9177-z

[14] Evans, G.C. (1972) The Quantitative Analysis of Plant Growth. Blackwell, Oxford. 